УДК 37.011.3-051

DOI: $10.15330 /$ esu. $16.117-124$

\section{Тетяна Потапчук,}

доктор педагогічних наук, професор,

ДВНЗ “Прикарпатський національний університет імені Василя Стефаника"

(м. Івано-Франківськ)

Tetiana Potapchuk,

doctor of pedagogical sciences, Professor,

Vasyl Stefanyk Precarpathian national university

(Ivano-Frankivsk, Ukraine)

tatvolod@ukr.net

\section{Наталія Анненкова,}

в. о. доцента,

Національної Музичної Академії України

ім.П.Чайковського (м. Київ, Україна)

Nataliia Annenkova,

Associate Professor, Ukrainian National Tchaikovsky

Academy of Music (Kyiv, Ukraine)

tatvolod@ukr.net

\title{
ДО ПРОБЛЕМИ ПРОФЕСПЙНОГО РОЗВИТКУ МАЙБУТНЬОГО ВИКЛАДАЧА
}

\section{TO THE PROBLEM OF PROFESSIONAL DEVELOPMENT OF FUTURE TEACHER}

У статті визначені загальні иляхи оптимізачії системи професійного розвитку викладача, орієнтованого на саморозвиток, узагальнюючи головні теоретичні позичї цодо сутності компетентнісної професійної освіти, т̈ структурної організачій, системотворних параметрів якості: а) подолання пріоритетності інформачійно-репродуктивної системи післядипломної освіти, методів та технологій ї̈ реалізацій, орієнтачї на усереднений, типовий рівень професійної діяльності викладача; б) забезпечення суб́'єктної позичії педагога в процесі професійного розвитку, програмувания методики підвищения професійної компетентності, орієнтуючись на власний потенціал розвитку, особистісну орієнтованість освітньої діяльності, ичо реалізується за індивідуальною траєкторією; в) сприяния переходу від зовнішнього управліния освітнім прочесом до самоуправліния, активуючи прочеси самодіагностики, самоаналізу, самопрограмування.

Ключові слова: професійний розвиток, освітній проџес, неперервна освіта, модернізачії організації навчального прочесу, система підвищення кваліфікачії педагогічних кадрів.

The article outlines the general ways of optimizing the system of professional development of a self-developed teacher, summarizing the main theoretical positions regarding the essence of competent professional education, its structural organization, system-quality parameters of quality: a) overcoming the priority of the information-reproductive system of postgraduate education, methods and technologies for its implementation, orientation towards averaged, typical level of professional activity of a teacher; b) ensuring the subject's position of the teacher in the process of professional development, programming methodology for increasing professional competence, focusing on their own development potential, the personal orientation of educational activity, implemented on the individual trajectory; c) facilitating the transition from external management to self-management, activating processes of self-diagnosis, self-analysis, selfprogramming.

The problem of professional development is the subject of active research in the world of educational space, while taking into account the following terms: teacher development, professional development, professional self-development, continuing education, education throughout life, and others. 
It was important to define how the problems of continuity of professional education and professional, personal self-development in its context are realized at different levels of the formation of the system of teaching activity and in specific forms of the educational process at the transition to the technology of competence education. The transition period to the new educational standards is rather complicated, because it is about changing the formula of educational activity, the relationship of participants in the pedagogical process, orientation to other educational, life values.

Key words: professional development, educational and process, continuous education, modernization of organization of educational process, system of professional development of pedagogical personnel.

Постановки проблеми. Проблема професійного розвитку є об'єктом активних наукових досліджень у світовому освітньому просторі, при тому послуговуючись термінами: розвиток викладача, професійний розвиток, професійний саморозвиток, неперервна освіта, освіта упродовж життя та інші. Досліджуючи методологічні, теоретичні, практичні основи забезпечення оптимізації професійного розвитку викладача, зокрема його саморозвитку як основи навчання впродовж життя, були проаналізовані літературні джерела, що стосуються як найбільш актуальних проблем, так і загальних стратегічних тенденцій та напрямків розвитку професійної компетентності педагога в Україні, технологічних схем та практичних умов їх реалізації. Важливо було визначити як проблеми неперервності професійної освіти та професійного, особистісного саморозвитку у ії контексті реалізуються на різних рівнях формування системи педагогічної діяльності та в конкретних формах навчально-виховного процесу на етапі переходу на технології компетентнісної освіти. Перехідний період до нових освітніх стандартів є досить складним, оскільки йдеться про зміну формули освітньої діяльності, взаємовідносин учасників педагогічного процесу, орієнтацію на інші освітні, життєві цінності.

У монографії “Вища освіта України в умовах глобалізації суспільства” В. Олійник, О. Отич вказують на важливість процесів саморозвитку, самовдосконалення викладача в системі післядипломної освіти як чинника забезпечення іiі неперервності: “для забезпечення якості людського капіталу в Україні необхідно посилити увагу до формування у майбутніх фахівців компетентності самовдосконалення, шо пов'язано з утвердженням у суспільстві знань ідеї безперервної освіти та стрімким розвитком освіти дорослих як важливої складової освіти впродовж життя" [9, с. 9-30].

Аналіз останніх наукових досліджень і публікацій. Проблема професійнопедагогічного розвитку та саморозвитку, підвищення професійної компетентності майбутнього викладача $\epsilon$ складною та багатоаспектною, тому різні напрямки, форми та методи професійного розвитку особистості були предметом наукових досліджень як вітчизняних, так і зарубіжних науковців (Г. Балл, І. Дичківська, І. Зязюн, Ю. Пелех, С. Сисоєва, В. Семіченко та ін.).

Також слід зазначити, що професійний розвиток викладача досліджуються у контексті: філософії освіти (О. Антонова, I. Зязюн, В. Кремень, О. Отич), професійної освіти (Л. Павленко, С. Сисоєва, І. Якухно) професійно-педагогічного розвитку викладача (В. Маслов, Л. Сташенко, Л. Чернікова, О. Шевченко, І. Якухно). Питання модернізації організації навчального процесу в системі підвищення кваліфікації педагогічних кадрів, інших форм післядипломної освіти досліджувалися в роботах Л. Даниленко, А. Кузьмінського, В. Лугового, В. Олійника, О. Отич, Н. Протасової, І. Якухно та ін. 
Аналіз зазначених вище наукових праць щодо професійної готовності майбутніх викладачів до заявлених реформ в системі освіти, дав можливість виділити проблеми, що є особливо актуальними, серед них:

- консервативність педагогічної спільноти, недостатній рівень готовності до продуктивного саморозвитку;

- недостатній рівень сформованості мотиваційної основи до професійного зростання викладача, забезпеченості адекватним інформаційно-методичним інструментарієм;

- відсутність мобільного діагностичного інструментарію для контролю якості професійної діяльності педагога у масовому масштабі, врахування іїі результатів для визначення статусних позицій кожного в системі;

- недостатній рівень дієвості, мобільності системи післядипломної освіти, орієнтованої на неперервність, мотивацію до професійного, особистісного саморозвитку педагога.

Мета статті - розглянути проблеми професійного розвитку майбутнього викладача у наукових дослідженнях.

Виклад основного матеріалу дослідження. На радикальність реформ освітньої сфери, пов'язаних з переосмисленням формули освітньої діяльності, умов забезпечення іiі неперервності, відповідно, функцій викладача в системі інноваційної освіти на сучасному етапі іiі розвитку вказують українські науковці Т. М. Десятов, І. Ф. Зязюн, В. Г. Кремень, В. І. Куценко, Л. П. Пуховська та ін.

Так, I. А. Зязюн стверджує, що "Важливішими цілями створення системи неперервної освіти є: по-перше, творча діяльність спеціаліста, здатність до гнучкої їі переоріснтації згідно зі змінами в системі соціальних i культурних інститутів сучасного суспільства, орієнтованого на людські цінності; по-друге, формування особистісних якостей людини, які визначають не лише іiі суто професійні характеристики, а й стиль мислення, рівень культури, інтелектуальний розвиток [5, с. 9].

Аналіз літературних джерел 3 питань модернізації педагогічної освіти всіх рівнів, у тому числі післядипломної, дає можливість акцентувати увагу на найбільш значущих ¥ї тенденціях (лат. tendentia, від tendo - прагну, прямую). Дослідник В. Маслов визначає тенденцію як “узагальнююче поняття, яке втілює в собі суттєві постійні протиріччя, умови, фактори тощо, які носять систематичний прояв i здійснюють суттєвий вплив на якість функціонування системи в цілому та іi структурних компонентів". При цьому автор зазначає, що тенденція $є$ формою прояву законів, які взагалі не мають іншої реальності, а відображаються у наближеному вигляді, у тенденції [8, с. 40-41]. Питання тенденцій модернізації освітньої діяльності, навчального процесу в системі підвищення кваліфікації педагогічних кадрів, інших форм післядипломної освіти досліджувалися в роботах Л. Даниленко, А. Кузьмінського, В. Лугового, В. Олійника, Н. Протасової, І. Якухно.

У контексті зазначеної проблеми особливої актуальності набули питання самоосвітньої діяльності сучасного викладача, які найбільшою мірою забезпечують неперервність, особистісну орієнтованість процесу його професійного розвитку.

Глибоко та системно досліджені підходи до оптимізації підвищення кваліфікації педагогічних працівників у системі неперервної освіти у дослідженнях таких учених як Т. Десятов, І. Зязюн, С. Сисоєва, А. Чміль та ін.

Як зазначає український дослідник С. Сисоєва, "Смислом і метою освіти є Людина в постійному (впродовж життя) розвитку. Кінцевий підсумок освіти внутрішній стан людини на рівні потреби пізнавати нове, освоювати знання, 
виробляти матеріальні й духовні цінності, допомагати ближньому, бути добротворцем" [10, с. 90].

Безальтернативним $є$ судження, що сучасний викладач повинен інтегруватися у систему розвитку інноваційної освіти, що має тенденцію до постійних змін, які диктуються змінами соціально-економічного розвитку держави, відповідно, зміною попиту на відповідний тип особистості молодої людини, здатної не лише до них адаптуватися, а і бути суб'єктом інноваційного розвитку у всіх сферах життєдіяльності. Як зазначає Д. І. Дзвінчук, “...ннайближчими роками не лише поглибиться наша участь у Болонському процесі, а все українське суспільство обере собі європейські взірці життедіяльності і відмовиться від застарілих та непридатних для майбутнього заокеанських філософських i соціальних поглядів та економічних моделей" [4, с. 25].

Тому сучасний викладач повинен постійно розвиватися як в особистісному, так i в професійному аспектах. Процес $\epsilon$ перманентним, “пов'язаним 3 удосконаленням їх професійної діяльності i забезпеченням успішності студентів. Ефективність професійного розвитку структурована: лідерство, знання, доступні ресурси, високий рівень співробітництва, відповідне оцінювання роботи й підтримка" [1, с. 154].

Проблеми професійного розвитку та саморозвитку майбутніх викладачів розглядаються на основі різних методологічних підходів, які, відповідно, забезпечують визначеність головних орієнтирів, цілеспрямованість, системність процесу. Найбільш поширеними серед них є наступні:

Андрагогічний підхід, який орієнтує на формування освітнього процесу, враховуючи особливості навчання дорослої людини. На основі досліджень таких зарубіжних учених як: П. Джарвис, Дж. Д'юі, Е. Ліндеман, М. Ноулз, обгрунтовується позиція щодо необхідності навчання людей з якомога більшим урахуванням їх наявного досвіду у відповідній сфері діяльності, особистісних характеристик як суб'єкта розвитку.

Н. Протасова [11], В. Пуцов [13] та інші досліджують проблеми теорії і практики андрагогічної організації навчання. Узагальнюючи позиції дослідників цього підходу до організації навчання, були виділені наступні характеристики:

- високий рівень, самостійності, індивідуалізації своєї освітньої, самоосвітньої діяльності, тенденції до посилення самокерованості процесу;

- розвиток власного досвіду діяльності, реалізація освітньої діяльності на основі взаємодії досвідів того, хто вчить, та того, хто вчиться;

- орієнтованість навчальної діяльності на актуальні потреби реальної практики професійної діяльності викладача.

В системі післядипломної освіти викладачів широкого використання набув акмеологічний підхід (акме від грец. - вершина, квітуча пора), який асоціюється 3 періодом найвищих досягнень людини, їі зрілістю у професійній діяльності, життєвій практиці та ін. Як зазначає Б. Ананьєв, педагогічна акмеологія є наукою про закономірності виших досягнень у цілісному розвитку людини на кожному іiі віковому етапі у процесі неперервної освіти [3, с. 143].

Методологічні основи досягнення професійного акме в освітній діяльності досліджували О. Анісімов, О. Бодальов, А. Деркач, А. Маркова, Є. Селезньова та ін.; у педагогічній акмеології досліджували В. Вакуленко, І. Зязюн, Н. Кузьміна, В. Максимова та ін. Так, Н. Кузьміна стверджус, що: “Акмеологія - нова галузь наукових знань в системі наук про людину - досліджує фундаментальні закономірності творчості і самосвідомості людини" [2, с. 34]. 
Водночас, акмеологічний підхід дає змогу з'ясувати суб'єктивні та об'єктивні фактори, які сприяють досягненню вершин професіоналізму людини, педагога у тому числі: це, з одного боку - якість отриманої базової професійної освіти, з іншого потенщіал розвитку, здатність до системної самоосвіти.

Отже, акмеологічний підхід трактується як особливий методологічнотехнологічний напрям, якому властива постійна орієнтованість на перспективи розвитку. Характерними ознаками цього підходу $є$ такі:

- орієнтація на професійну зрілість і майстерність як об'єкт удосконалення на всіх етапах життя й діяльності людини;

- усебічний розвиток свідомості й діяльності груп (товариств), переконаність у можливості масового вдосконалення;

- оптимістичне бачення людини, іiі можливостей, майбутнього; проектування вищих досягнень як окремими особами, так і групами й товариствами [3, c. 143].

Акмеологічний та андрагогічний підходи в системі післядипломної освіти $\epsilon$ взасмопов'язаними та взаємозалежними, вони мають багато спільного, зокрема, їх характеризує індивідуальна, особистісна спрямованість освітнього процесу, актуалізація наявного досвіду, його осмислення через призму реалізації високих цілей професійної діяльності, досягнення яких буде слугувати, передусім, чинником професійно-педагогічного саморозвитку, особистісної самореалізації.

Компетентнісний підхід. Шляхи вдосконалення підготовки педагогічних працівників у післядипломній педагогічній освіті з позицій компетентнісного підходу, концептуальні засади професійної компетенції та компетентності викладача, методологічні засади розвитку професійної компетентності педагогів в умовах післядипломної педагогічної освіти були об'єктом досліджень багатьох українських та зарубіжних вчених, зокрема Л. Даниленко, І. Зязюна, Н. Кузьміної, В. Маслова, О. Овчарук, О. Пєхоти, Дж. Равена, А. Хуторського, Л. Чернікова, І. Якухно та ін. [12].

Відомий український науковець І. Зязюн зазначає, що “...компетентність як екзистенціональна властивість людини $є$ продуктом власної життєтворчої активності людини, ініційованої процесом освіти..." [6, с. 11].

Професійний розвиток, саморозвиток учителя ускладнюється особливостями перехідного періоду від освіти інформаційно-репродуктивної до компетентнісної, тому, окрім традиційних знань, які відповідають за розвиток професіоналізму викладача, враховуючи постійне оновлення програм, змісту освітньої діяльності, форм та методів іiі реалізації, вчитель, який переходить на інноваційну особистісно орієнтовану освіту, має розуміти теоретико-практичні основи інноваційної діяльності, особливості перехідного періоду, що передбачає радикальні зміни, суттєве оновлення формули організації освітньої діяльності. Йдеться про розвиток професійної компетентності як умови адаптації до інноваційних освітніх стандартів, технологій їх реалізації.

Професійний розвиток сучасного викладача спрямований на оптимізацію саморозвитку, тобто на формування здатності бути суб'єктом формування власної концепції та моделі діяльності, орієнтуючись на власний досвід та особистісні характеристики, а також формувати ставлення до перманентної професійної освіти, у iii контексті - особистісного саморозвитку як головної умови успішної професійнопедагогічної діяльності, забезпечення конкурентоздатності на ринку освітніх послуг. 
Отож, йдеться про оновлення освітньої діяльності як на рівні методології, теорії, так і змістово-технологічних аспектів їх реалізації. Неперервність системи професійної освіти може бути забезпечена лише за умови, якщо система освітньої діяльності всіх рівнів буде базуватися на спільних концептуальних основах, забезпечуючи принцип наступності, послідовності, неперервності розвитку систем.

Усі напрямки модернізації системи професійної підготовки майбутнього викладача логічно мають трансформуватись і на систему післядипломної освіти, систему розвитку та саморозвитку викладача, забезпечивши приведення основ освітньої діяльності всіх рівнів і до відповідних базових освітніх стандартів.

Реальна компетентність майбутнього викладача визначається саме вмінням використати набуті теоретичні знання в практичній діяльності. Педагогічний процес складний і багатовимірний і кожна конкретна педагогічна задача потребує передусім iii осмислення через призму відповідних теоретичних основ. Педагог повинен самостійно визначити суть проблеми, поставити адекватну задачу, знайти ефективні способи ії вирішення, проаналізувати та визначити рівень ефективності її вирішення. Лише високий рівень теоретичної компетентності, усвідомленого володіння теоретичними знаннями сформує відповідні практичні орієнтації в кожній конкретній педагогічній ситуації.

Ще у контексті класичної педагогіки значна увага дослідників приділялась проблемі професійного саморозвитку майбутнього викладача, формування його готовності до роботи в системі суб'єкт-суб'єктної взаємодії учасників педагогічного процесу. Так, В. Крутецький досліджував проблеми систематизації та диференціації здібностей викладача стосовно забезпечення діалогічної взаємодії зі студентами [7], Г. Щукіна акцентувала увагу на важливості формування суб'єкт-суб'єктних взаємовідносин, які лежать в основі освітньої системи, а також важливості забезпечення професійної підготовки та саморозвитку майбутнього викладача, який буде спроможним організувати навчальний процес такого рівня [15, с. 64].

Російський вчений-педагог Л. В. Занков відмічає, “Дидактика і методика того чи іншого предмета орієнтують учителя у питаннях теорії навчання, рекомендують відповідні методичні способи і прийоми. Все це, так би мовити, дано вчителю. Завдання, при тому далеко не просте, полягає в тому, щоб правильно і $з$ найбільшим результатом використати ту зброю, яку він отримує від педагогічної науки" [14, c. 169].

Висновки та перспективи матеріалу дослідження. Отже узагальнення позицій наукових досліджень стосовно перспектив підвищення ефективності професійного розвитку майбутнього викладача дало можливість виділити загальні тенденції осучаснення освіти, пов'язані 3 проблемами оптимізації професійнопедагогічного саморозвитку майбутнього викладача, серед них: тенденція до фундаменталізації, інтеграції, цілісності неперервності освітнього процесу; тенденція до інформатизації освіти; тенденція до забезпечення особистісної орієнтованості освіти та ін.

\section{Література}

1. Авшенюк Н., Костіна Л. Професійний розвиток учителя як проблема порівняльної педагогіки Порівняльна професійна педагогіка. 2014. №4 (2). С. 150-156.

2. Акмеология 2000: Методические и методологические проблемы ; под ред. Н.В. Кузьминой, А.М. Зимичева. Санкт-Перербург : АА, 2000.

3. Данилова Г. С. Педагогічний професіоналізм у контексті акмеології. Педагогічна освіта теорія і практика. Психологія і практика : зб. наук. праць. Київ : КМПУ ім. Б. Д. Грінченка, 2006. № 5. C. 74-80. 
4. Дзвінчук Д. І. Засади управління і вибір цілей діяльності освітньої системи в контексті європейського виміру. Вища освіта України. 2006. № 2. С. 20-26.

5. Зязюн I. А. Неперервна освіта: концептуальні засади і сучасні технології. Творча особистість y системі неперервної професійної освіти : мат. міжнар. наук. конф. (16-17 травня 2000 р., м. Харків) ; за ред. С. О. Сисоєвої і О. Г. Романовського. Харків : ХДПУ, 2000. С. 8-16.

6. Зязюн I. А. Філософія поступу і прогнозу освітньої системи. Педагогічна майстерність: проблеми, почуки, перспективи : монографія. Київ; Глухів : РВВ ГДПУ, 2005. С. 10-18.

7. Крутецкий В. А., Балбасова Е. Г. Педагогические способности, их структура, диагностика, условия формирования и развития : учеб. пособ. Москва : Прометей, 1991. 102 с.

8. Маслов В. І., Боднар О. С., Гораш К. В. Наукові основи та технології компетентного управління загальноосвітнім навчальним закладом : монографія. Тернопіль : Крок, 2012. 320 с.

9. Олійник В., Отич О. Післядипломна педагогічна освіта в контексті глобальних цивілізаційних змін. Вища освіта України в умовах глобалізації суспільства : монографія / редкол. : Л. Г. Горяна, Н. О. Терентьєва; за наук. ред. М. Б. Євтуха. Київ : Агроосвіта, 2015. 300 с.

10. Пелех Ю. В. Ціннісно-смисловий концепт професійної підготовки майбутнього педагога : монографія ; за заг. ред. М. Б. Свтуха. Рівне : Тетіс, 2009. 400 с.

11. Протасова Н. Андрагагічна ідея і післядипломна освіта : постановка проблеми. Шлях освіти. 1998. № 3. C. 13-15.

12. Пуховська Л. П. Європейський вимір шкільної й педагогічної освіти: етапи розвитку. Післядипломна освіта в Україні. 2008. № 2. С. 80-82.

13. Пуцов В. І., Набока Л. Я. Особливості навчання дорослої людини : навч. посіб. Київ : ЦІППО АПН України, 2004. $56 \mathrm{c}$.

14. Содружество ученого и учителя: Л. В. Занков. Беседы с учителями. Работаем по системе Л. В. Занкова : Кн. для учителя / сост. М. В. Зверева, Н. К. Индик. Москва : Просвещение, $1991.272 \mathrm{c}$.

15. Щукина Г. И. Роль деятельности в учебном процессе : Кн. для учителя. Москва : Просвещение, 1986. 142 с.

\section{References}

1. Avshenyuk N., Kostina L. Professional development of the teacher as a problem of comparative pedagogy. Comparative professional pedagogy. 2014, No. 4 (2). Pp. 150-156.

2. Akmeologiya 2000: Methodological and methodological problems; ed. N.V. Kuzmina, A.M. Zimicheva Saint-Pererburg: AA, 2000.

3. Danilova G.S. Pedagogical professionalism in the context of acmeology. Pedagogical Education: Theory and Practice. Psychology and Practice: Sb. sciences works Kiev: KMPU them. B. D. Grinchenko, 2006. No. 5. P. 74-80.

4. Dzvinchuk D.I. Principles of management and choice of goals of the educational system in the context of European dimension. Higher education of Ukraine. 2006. No. 2. P. 20-26.

5. Zyazun IA. Philosophy of progress and forecast of the educational system. Pedagogical skills: problems, searches, perspectives: monograph. Kiev; Glukhiv: RVB GDPU, 2005. 10-18.

6. Krutetsky VA, Balbasova E. G. Pedagogical abilities, their structure, diagnostics, conditions of formation and development: studies. way. Moscow: Prometheus, 1991. 102 p.

7. Maslov V. I., Bodnar O. S., Gorash KV. Scientific bases and technologies of the competent management of a comprehensive educational institution: a monograph. Ternopil: Step, 2012.320 p.

8. Oliynyk V., Otich O. Postgraduate pedagogical education in the context of global civilizational changes. Higher education of Ukraine in the conditions of globalization of society: monograph / redkol. : L.G. Goryana, N.O. Terentyev; for sciences edit M. B. Yevtuha. Kyiv: Agro-education, 2015.300 p.

9. Pelech $\mathrm{Yu}$. V. Valuably-semantic concept of professional training of the future teacher: monograph; for community edit M. B. Yevtuha. Rivne: Tetris, 2009. 400 p.

10. Protasova N. Andragagic idea and postgraduate education: problem statement. The path of education. 1998. No. 3. P. 13-15.

11. Pukhovska L.P. European dimension of school and pedagogical education: stages of development. Postgraduate education in Ukraine. 2008. No. 2. P. 80-82.

12. Putsov V. I., Naboka L. Ya. Peculiarities of adult education: curriculum. manual Kyiv: TsIPPO of the Academy of Pedagogical Sciences of Ukraine, 2004. 56 p. 
13. Commonwealth of Scientists and Teachers: L.V. Zankov. Conversations with teachers. We work under the system of L.V. Zankov: Kn. for the teacher / sost. MV Zvereva, N.K. Indik. Moscow: Enlightenment, 1991. 272 pp.

14. Shchukina G.I. The Role of Activities in the Educational Process: Kn. for the teacher. Moscow: Enlightenment, 1986. $142 \mathrm{p}$.

Одержано статтю: 23.05.2019

Прийнято до друку: 06.06.2019

УДК 378:373.3]:005.336.2

DOI: $10.15330 /$ esu. 16.124-129
Д.митро Пріма,

кандидат педагогічних наук, доцент, Волинський інститут післядипломної педагогічної освіти (м. Луцьк, Україна)

Dmytro Prima,

Candidate of pedagogical sciences $(\mathrm{PhD})$, Associate Professor, Volyn Institute of Postgraduate Pedagogical Education (Lutsk, Ukraine) primar@ukr.net

\section{ПРОФЕСІЙНА ОРІЕНТАЦІЯ - ПЕРЕДУМОВА ФОРМУВАННЯ ПРОФЕСІЙНОГО САМОВИЗНАЧЕННЯ МАЙБУТНЬОГО ВЧИТЕЛЯ ПОЧАТКОВОЇ ШКОЛИ}

\section{PROFESSIONAL ORIENTATION AS A PRECONDITION OF FORMING THE PROFESSIONAL SELF-DEFINITION OF THE FUTURE ELEMENTARY SCHOOL TEACHER}

У статті синтезовано розкрито аспекти сутнісної характеристики професійної орієнтації як науково-практичної системи підготовки особистості до свідомого професійного самовизначення, передумови формування професійного самовизначення майбутнього вчителя початкової школи. Внесено деякі уточнення щодо трактування ключових понять "професія", "професійна оріснтачія", "професійне самовизначения" як суміжних, щео пов'язані з профорієнтачією. Професійне самовизначення розглядається як довготривалий, динамічний, иілісний прочес входження у професію, результат вибору $i$ проектування майбутньої педагогічної діяльності вчителя початкової школи, який відбувається в освітньому середовиці закладу вищої освіти иляхом усвідомленого й активного ставления студента до власної життсвої перспективи, до оволодіния майбутньою професією. Зроблено висновок, що професійна орієнтачія в сучасних умовах фахової підготовки майбутнього вчителя початкової иколи нової формачій, здатного $i$ спроможного втілювати у життя нові освітні настанови, стратегії, має досягти свойх головних иілей - його готовності до професійного самовизначення, що відповідає індивідуальним здібностям кожної особистості та потребам сучасного ринку прачі.

Ключові слова: майбутній учитель, початкова икола, професія, професійна оріснтачія, професійне самовизначения.

The article is synthesized the aspects of the essential characteristic of professional orientation as a scientific-practical system of person's training for conscious professional selfdetermination, the preconditions for the formation of professional self-determination of the future elementary school teacher. Some clarifications were given regarding the interpretation of the key concepts of "profession", "professional orientation", "professional self-determination" as adjacent, related to vocational guidance. Professional self-determination is considered as a longterm, dynamic, holistic process of entering the profession, the result of choosing and designing the future pedagogical activity of the elementary school teacher, which takes place in the educational environment of the institution of higher education through a conscious and active attitude of the 